University of Nebraska - Lincoln

DigitalCommons@University of Nebraska - Lincoln

Faculty Publications: Department of Entomology

1996

\title{
Identification of screwworm species by polymerase chain reaction-restriction fragment length polymorphism
}

David B. Taylor

University of Nebraska-Lincoln, dave.taylor@ars.usda.gov

Allen L. Szalanski

University of Nebraska-Lincoln

Richard D. Peterson II

University of Nebraska-Lincoln, padr20@yahoo.com

Follow this and additional works at: https://digitalcommons.unl.edu/entomologyfacpub

Part of the Entomology Commons

Taylor, David B.; Szalanski, Allen L.; and Peterson, Richard D. II, "Identification of screwworm species by polymerase chain reaction-restriction fragment length polymorphism" (1996). Faculty Publications: Department of Entomology. 207.

https://digitalcommons.unl.edu/entomologyfacpub/207

This Article is brought to you for free and open access by the Entomology, Department of at DigitalCommons@University of Nebraska - Lincoln. It has been accepted for inclusion in Faculty Publications: Department of Entomology by an authorized administrator of DigitalCommons@University of Nebraska - Lincoln. 


\title{
Identification of screwworm species by polymerase chain reaction-restriction fragment length polymorphism
}

\author{
DAVID B. TAYLOR, ALLEN L. SZALANSKI and \\ R ICHARD D. PETERSON, I I USDA, ARS Midwest Livestock Insects Research Laboratory, \\ Department of Entomology, University of Nebraska, U.S.A.
}

\begin{abstract}
Restriction fragment length polymorphisms in polymerase chain reaction amplified fragments (PCR-RFLP) of mitochondrial DNA were used to differentiate species of New World screwworms (Diptera: Calliphoridae). Twenty-seven restriction enzymes were screened on five regions of mtDNA. Eleven restriction fragment length patterns differentiated New World screwworm, Cochliomyia hominivorax (Coquerel), from secondary screwworm, Cochliomyia macellaria $(\mathrm{F}$.). Five restriction fragment length patterns were polymorphic in C.hominivorax while all fragment patterns were fixed in C.macellaria. Diagnostic restriction fragment length patterns were used for species diagnosis, whereas intraspecific variable patterns were used to characterize field samples and laboratory strains. The PCR-RFLP technique is flexible with regard to developmental stage of the sample and method of preservation. We were able to characterize specimens of all life stages from egg to adult including larvae preserved in alcohol and pinned adults. PCR-RFLP is rapid and inexpensive, enabling specimens to be characterized within $24 \mathrm{~h}$ for less than $\$ 2.50$.
\end{abstract}

Key words. Cochliomyia hominivorax, Cochliomyia macellaria, screwworm, mitochondrial DNA, PCR-RFLP, molecular taxonomy.

\section{Introduction}

New World screwworm, Cochliomyia hominivorax (Coquerel) (Diptera: Calliphoridae), is among the most important insect pests of livestock in neotropical regions. This pests was formerly distributed from the southern United States to northern Argentina and throughout much of the Caribbean (Guimaraes et al., 1983; Dear, 1985; Rawlins \& Mansingh, 1987). Eradication programmes have eliminated C.hominivorax from the United States, Mexico, Belize, Guatemala, El Salvador, Virgin Islands, and Puerto Rico (Graham, 1985; Vargas-Teran, 1991). Eradication programmes are active in the remaining countries of Central America.

Rapid international movement of livestock and travel have increased the likelihood of the introduction of C.hominivorax to eradicated zones or to regions where it is not native. Climatic models indicate that C.hominivorax could potentially colonize most of the tropical and semitropical regions of the world (Sutherst et al., 1989; F.A.O., 1991). C.hominivorax was introduced into Libya in 1988 (El Azazy, 1989), by sheep

Correspondence: Dr David B. Taylor, 305 Plant Industry Bldg, East Campus, UNL, Lincoln, NE 68583, U.S.A. imported from South America (Beesley, 1991). The Libyan introduction was eradicated at a cost of $\$ 78$ million (F.A.O., 1992; Lindquist et al., 1992; Vargas-Teran et al., 1994). C.hominivorax has been found in France, on a dog returning from Brazil (Chermette et al., 1982); in the United States, on a soldier wounded in Panama (Mehr et al., 1991); and in Australia, on a woman returning from Brazil (Searson et al., 1992). Fortunately, viable populations were not established from these introductions. Re-introductions or outbreaks of C.hominivorax have occurred in previously eradicated zones. C.hominivorax was eradicated from Curaçao in 1954 (Bushland et al., 1955), but the island was reinfested in 1971 (Snow et al., 1978). In Mexico, a C.hominivorax outbreak in 1992 and 1993 spread to within $250 \mathrm{~km}$ of the U.S. border and cost $\$ 9.5$ million to control ( $\mathrm{J}$. Wyss, personal communication). C.hominivorax are usually collected as larvae from infested hosts. Adult flies are rarely observed without special effort, even in areas with high populations. Although third-instar larvae are relatively easy to identify, second-instar larvae can be difficult (F.A.O., 1990; Spradbery, 1991). Frequently, larval samples received for identification are in poor condition due to mechanical damage while being extracted from the wound and/or poor preservation. In addition, an outbreak is 
frequently indicated by a small number of samples. A total of six C.hominivorax samples was collected in the 1993 Mexican outbreak.

Cochliomyia hominivorax co-exists with Cochliomyia macellaria (F.) the secondary screwworm, which is morphologically similar but behaviourally very different (Laake et al., 1936). C.macellaria is common and ranges into C.hominivorax-free regions, complicating the identification of screwworm samples.

Mobilization of a sterile insect technique (SIT) control programme to eradicate C.hominivorax is very expensive. Because a single female can lay up to 500 eggs per egg mass and can develop an egg mass every 3 days (Thomas \& Mangan, 1989), a control programme must be initiated as quickly as possible after detection to prevent the rapid expansion of an infestation. A model prepared by the Queensland Department of Primary Industry predicts that a screwworm infestation in tropical Australia would expand at a rate of $10 \mathrm{~km}$ per week (Queensland Department of Primary Industry, 1994). C.hominivorax populations can expand from their overwintering areas in the southern U.S. and Mexico at a rate of $50-60 \mathrm{~km} /$ week (Barrett, 1937). The need for a rapid response to a C.hominivorax introduction and difficulties associated with the identification of larval samples poses a dilemma for programme managers. With the finding of a questionable sample, they are left with the decision to initiate a control programme costing millions of dollars or wait for additional samples, possibly allowing the infestation to spread ( $\mathrm{J}$. Wyss, personal communication). A fast reliable technique is needed to identify and characterize all stages of C.hominivorax, including poorly preserved, field-collected specimens.

Taylor \& Peterson (1994) identified two allozyme loci, Fum and $M d h$, which are diagnostic between C.hominivorax and C.macellaria and five additional loci with less than $1 \%$ overlap, $A c o h, F d h, G c d, H a d h$ and $P g d h$. Unfortunately, specimens must be maintained below $-70^{\circ} \mathrm{C}$ to preserve allozyme activity for this analysis and expression of several of the allozymes is stage specific. Such storage conditions are frequently not available when screwworm larval samples are obtained. Cuticular hydrocarbons offer another option for screwworm identification; however, they vary with stage, age and sex (Pomonis \& Mackley, 1985; Pomonis, 1989).

DNA is more stable than the enzymes used for allozyme analysis and does not vary during the life cycle. Polymerase chain reaction (PCR) allows isolation and amplification of DNA fragments from small and poorly preserved specimens. Hall \& Smith (1991) used restriction enzyme analysis of PCR products (PCR-RFLP) to differentiate African and European honey bee races, and Simon et al. (1993) used PCR-RFLP to characterize periodic cicada broods. The latter authors indicated that the PCR-RFLP is less expensive and has higher resolution than standard RFLP analysis (Simon, 1991). Sperling et al. (1994) modified the PCR-RFLP technique to differentiate three species of blow flies. The latter authors used restriction fragment length differences in a 348 bp sequence from the mitochondrial COI gene. They were able to identify larval specimens which had been stored in $75 \%$ ethanol at room temperature for up to 1 month and adults which had been dried and stored at room temperature for 5 days.
The purpose of this study was to use the PCR-RFLP technique to identify field samples of C.hominivorax. In order to be useful, the technique must give unambiguous identifications of alcohol-preserved and dried samples. The technique should also be able to identify all stages of the life cycle based upon the same criteria. A second aim was to determine if PCR-RFLP can be used for intraspecific characterization of field-collected C.hominivorax samples.

\section{Materials and Methods}

Samples. Samples used for the geographic survey are listed in Table 1. All of these specimens had been stored at $-80^{\circ} \mathrm{C}$. In addition, we examined an adult C.hominivorax from Tapachula, Chiapas, Mexico, which had been pinned in 1982, a C.macellaria from Fargo, North Dakota, which had been pinned in 1991, six larval samples collected in Mexico from 1989 to 1991 and preserved in alcohol, and an egg mass preserved in alcohol for 2 months. None of these samples received special treatment during their storage period. We also examined several outbreak and questionable samples received by the Mexican-American Commission for the Eradication of Screwworm (Table 2). These included six samples, one larva each, from the 1992-93 outbreak of C.hominivorax in northeastern Mexico; an adult female collected on a livestock vessel in Quintana Roo, Mexico; an egg mass collected from a wound infested with larvae from other species of blow flies near Cintalapa, Chiapas, Mexico; larvae collected from a wound in a calf near Chiapa de Corzo, Chiapas, Mexico; and one of several pupae scattered on the desk of an official of the Mexican Department of Agriculture offices in Tuxtla Gutierrez, Chiapas, Mexico, by an unknown individual. These samples were collected from areas believed to be screwworm-free. Eight flies from the C.hominivorax strain currently in mass production, CR-91, were characterized for comparison to the outbreak and questionable samples. These were obtained from the production facility in Tuxtla Gutierrez, Chiapas, Mexico, in February 1994.

DNA extraction and amplification. Eggs (one egg mass, about $10 \mathrm{mg}$ ), larvae (whole first or second instar larvae or a quarter to

Table 1. Screwworm specimens analysed.

\begin{tabular}{lllll}
\hline Species & Location & $n$ & Origin & Stage \\
\hline \multirow{2}{*}{ C.hominivorax } & Tripoli, Libya & 2 & Colony & Adult \\
& Cañas, Costa Rica & 2 & Colony & Adult \\
& Rio Grande do Sul, Brazil & 2 & Field & Adult \\
& V-81, Veracruz, Mexico & 2 & Colony & Adult \\
& Jamaica & 1 & Field & Larvae \\
& Trinidad & 2 & Field & Larvae \\
& Cuba & 1 & Field & Pupae \\
& OW-87, Orange Walk, Belize & 2 & Colony & Adult \\
C.macellaria & Fargo, ND, U.S.A. & 2 & Colony & Adult \\
& Lincoln, Neb., U.S.A. & 2 & Field & Adult \\
& Tuxtla Guticrrez, Mexico & 2 & Field & Adult \\
& Cañas, Costa Rica & 2 & Field & Adult \\
& Rio de Janeiro, Brazil & 2 & Field & Adult \\
\hline
\end{tabular}


Table 2. Unknown and questionable field samples from Mexico.

\begin{tabular}{llll}
\hline Specimen & Location & Source & Datc \\
\hline $\begin{array}{c}\text { 1992-93 outbreak } \\
\text { GB-1361-92 }\end{array}$ & Panuco, Veracruz & Bovine & \\
GB-378-93 & Panuco, Veracruz & Bovine & December 1992 \\
GB-347-93 & Panuco, Veracruz & Bovine & 1 April 1993 \\
GB-397-93 & Gonzalez, Tamaulipas & Bovine & 21 May 1993 \\
GB-466-93 & Panuco, Veracruz & Bovine & 4 June 1993 \\
GB-977-93 & San Felipe Orizatlan, Hidalgo & Bovine & 17 June 1993 \\
1994 samples & & & \\
Adult & Quintana Roo & Livestock vessel & \\
Eggs & Cintalapa, Chiapas & Bovine & January 1994 \\
Larvae & Chiapa de Corzo, Chiapas & Bovine & 23 June 1994 \\
Pupae & Tuxtla Gutierrez, Chiapas & Desk & 14 July 1994 \\
\hline
\end{tabular}

an eighth third instar larvae), pupae (with and without puparia) and adult thoraces or heads were ground in $200 \mu \mathrm{l}$ lysis buffer ( $100 \mathrm{~mm} \mathrm{NaCl}, 100 \mathrm{~mm}$ EDTA, $100 \mathrm{~mm}$ Tris, 0.5\% SDS, pH 7.5). Proteinase $\mathrm{K}, 4 \mu \mathrm{g}$, was added and the lysis mixture was incubated at $55^{\circ} \mathrm{C}$ for $3 \mathrm{~h}$. RNAase, $2 \mu \mathrm{g}$, was added and the samples were incubated at $37^{\circ} \mathrm{C}$ for $20 \mathrm{~min}$. Following the addition of $100 \mu$ of phenol, samples were incubated for 10 min of $55^{\circ} \mathrm{C} .100 \mu \mathrm{l}$ chloroform/isoamyl alcohol (24:1) was added and samples were centrifuged for $5 \mathrm{~min}$. The aqueous (upper) phase was transferred to a new $1.5 \mathrm{ml}$ centrifuge tube to which $200 \mu \mathrm{l}$ of chloroform/isoamyl alcohol was added and the samples were again centrifuged for $5 \mathrm{~min}$. The aqueous phase was transferred to a new $1.5 \mathrm{ml}$ centrifuge tube to which $400 \mu \mathrm{l}$ of $100 \%$ ethanol was added. The tubes were centrifuged for $20 \mathrm{~min}$ and the ethanol was decanted. The DNA pellet was washed with $70 \%$ ethanol and centrifuged for $7 \mathrm{~min}$. The ethanol was decanted and the pellet was vacuum-dried and resuspended in 25-100 $\mu$ of sterile, Nanopure (Barnstead, Dubuque, Iowa) water and stored at $4^{\circ} \mathrm{C}$.

Five mitochondrial DNA (mtDNA) amplicons were studied (Table 3): (1) a 348 base-pair (bp) region [lengths are based on the Drosophila yakuba mtDNA map (Clary \& Wolstenholme, 1985)] of the cytochrome oxidase I gene, (2) a $137 \mathrm{bp}$ region of the cytochrome oxidase II gene, (3) a 257 bp region of the NADH dehydrogenase 4 gene, (4) a 345 bp region including the end of the cytochrome $b$ gene, the tRNA (serine) gene and the beginning of the NADH dehydrogenase 1 gene, and (5) a $320 \mathrm{bp}$ region including the end of NADH dehydrogenase
1 gene, tRNA (leucine) gene, and the beginning of the large ribosomal RNA gene. For amplification, $1 \mu$ of sample DNA was added to a reaction mixture containing $2.5 \mu \mathrm{l}$ of reaction buffer (Perkin-Elmer, Norwalk, Conn.), $2 \mu$ of dNTP mix (10 mm each, dATP, dTTP, dCTP and dGTP), $1 \mu$ of each primer (20 mm), 1.0 unit of Taq polymerase (Perkin-Elmer) and deionized water to a volume of $25 \mu$ l. Amplifications were done in a Perkin Elmer Cetus Model 9600 thermocycler programmed for 35 cycles of $92^{\circ} \mathrm{C}$ for $1 \mathrm{~min}, 42^{\circ} \mathrm{C}$ for $1 \mathrm{~min}$, and $72^{\circ} \mathrm{C}$ for 1 or $2.5 \mathrm{~min}$. Amplification products were stored at $4^{\circ} \mathrm{C}$.

Restriction endonuclease digests. Twenty-seven restriction enzymes (RE, Alu I, Apo I, Ase I, Ava I, Ban II, Bfa, I, Bsr I, Dde I, Dpn II, Dra I, EcoR I, EcoR V, Hae III, Hinc II, Hind III, Hinf I, Hpa I, Mse I, Msp I, Pvu II, Rsa I, Sac I, Sau96 I, ScrF I, Ssp I, Taq $I$ and $X b a I$ ) were screened on four adult C.hominivorax, two each from colonies that originated from Cañas, Costa Rica and Libya and four adult C.macellaria, two from a colony originating in Fargo, N.D., U.S.A., and two field collected adults from Rio de Janeiro, Brazil. REs which resulted in diagnostic digest patterns were tested on the other populations (Table 1) to verify that intraspecific variability would not confound species identification.

Digests were done using $1 \mu \mathrm{l}$ of crude PCR product, $0.2 \mu \mathrm{l}$ enzyme (New England Biolabs, Beverly, Mass.). $1 \times$ buffer (New England Biolabs) and water to bring the volume to $5 \mu \mathrm{l}$ in $200 \mu \mathrm{l}$ tubes. Samples were incubated at $37^{\circ} \mathrm{C}$ for $3-16 \mathrm{~h}$, followed by $65^{\circ} \mathrm{C}$ for $10 \mathrm{~min}$ and held at $4^{\circ} \mathrm{C}$.

Table 3. Polymerase chain reaction primers.

\begin{tabular}{|c|c|c|c|c|c|}
\hline Amplicon & $\begin{array}{l}\text { Forward } \\
\text { primer }\end{array}$ & $\begin{array}{l}\text { Sequence } \\
5-3\end{array}$ & $\begin{array}{l}\text { Reverse } \\
\text { primer }\end{array}$ & $\begin{array}{l}\text { Sequence } \\
5-3\end{array}$ & Location" \\
\hline 1 & Sperling- $2^{\mathrm{b}}$ & CAGCTACTTTATGAGCTTTAGG & Sperling- $3^{\mathrm{b}}$ & CATTTCAAGCTGTGTAAGCATC & $2474-2821$ \\
\hline 2 & $\mathrm{C} 2 \mathrm{~F}^{\mathrm{d}}$ & GGTCAATGTTCAGAAATTTGTGG & Sperling-4 & GAGACCATTACTTGCTTTCAGTCATCT & $3662-3798$ \\
\hline 3 & $\mathrm{~N} 4 \mathrm{R} 2^{\circ}$ & GTAGGAGGAGCTGCTATATTAG & $\mathrm{N} 4 \mathrm{~F}_{3}$ & GCTTATTCATCGGTTGCTCA & $8481-8737$ \\
\hline 4 & $P 6$ & ACATGAATTGGAGCTCGACCAGT & $\mathrm{P} 7^{\mathrm{d}}$ & GGTACATTACCTCGGTTTCGTTATGAT & $11523-11867$ \\
\hline 5 & $\mathrm{P} 4$ & GGTCCCTTACGAATTTGAATATATCCT & P5 & GAGTTCAAACCGGCGTAAGCCAGGT & $12559-12878$ \\
\hline
\end{tabular}

"Drosophila vakuba miDNA map (Clary \& Wolstenholme. 1985). " Sperling et al. (1994). " Pruesss et al. (1992). “ K. Pruess (personal communication). 
Electrophoresis. $1 \mu \mathrm{l}$ of loading buffer (10\% Ficoll 400): (Sigma Chemical Co.. St. Louis, Mo.), 0.25\% Bromophenol Blue (Sigma Chemical Co., St. Louis, Mo.), $50 \mathrm{~mm}$ EDTA, $10 \mathrm{~mm}$ Tris-HCl $\mathrm{pH} 7.5$, was added to the $5 \mu \mathrm{l}$ digest product. Fragments were separated by vertical polyacrylamide gel electrophoresis (PAGE). The entire digest product was loaded onto a $10 \% \mathrm{gel}$ ( $1 \times$ Tris:borate:EDTA (TBE), $0.5 \%$ Photoflo-200; (Kodak, Rochester, NY; $0.15 \%$ TEMED and $0.05 \%$ ammonium persulelate). Hoefer (Hoefer Scientific Instruments, San Francisco, Calif.) SE 600 electrophoresis units with $16 \times 20 \mathrm{~cm}$ by $0.75 \mathrm{~mm}$ gels and twenty-eight well combs were used for electrophoresis. Gels were run in $1 \times \mathrm{TBE}$ buffer at a constant $300 \mathrm{~V}(15 \mathrm{~mA} / \mathrm{gel})$ for $1.5 \mathrm{~h}$ at $20^{\circ} \mathrm{C}$. Gels were stained for $5 \mathrm{~min}$ with ethidium bromide $(1 \mu \mathrm{g} / \mathrm{ml})$, rinsed in distilled water, and interpreted on an ultraviolet $(312 \mathrm{~nm})$ transilluminator. A molecular size standard, pGEM (Promega, Madison, Wis.), was included on each gel. Fragment sizes were calculated with a computer program, GEL-JML (LaCroix, 1994) and extrapolated. Mitochondrial DNA sequences of Drosophila yakuba (Clary \& Wolstenholme, 1985), Anopheles gambiae (Beard et al., 1993), and Anopheles quadrimaculatus (Mitchell et al., 1993) were examined and, when probable restriction sites were apparent, fragment lengths were adjusted.

\section{Results}

We successfully amplified DNA from eggs, first, second and third instar larvae, pupae and adults. Adequate DNA product was obtained for all five primer pairs from dried pinned adults 13 years old, larvae stored in alcohol for 3-5 years, pupae stored in alcohol, and eggs stored in alcohol. Initially, we had difficulties amplifying DNA from third-instar larvae and larvae with a large amount of blood in the gut. By using only a quarter to an eighth of a third-instar larva for each DNA isolation and by repeating the ethanol precipitation step we were able amplify DNA from these samples.

The mtDNA fragments consistently migrated at a rate representative of a size about $10 \%$ larger than their actual size relative to the molecular weight marker. The fragment sizes indicated by the GEL-JML program were adjusted to take this into account. For most of the digests, a probable restriction site was located within a few base-pair of the predicted cut site based upon the fragment lengths. We considered a site to be probable when the site existed in D.yakuba or when a single base-pair change, not affecting the amino acid coded for, would produce the site. All of the variation observed within and between species could be explained by the presence or absence of one or two restriction sites except for $E c o R V$ for amplicon 1 and $M s e I$ for amplicon 3 . For $E c o R V$ the second fragment clearly and consistently migrated slower in C.hominivorax. This may be the result of a conformational difference rather than a site change. The Mse I digest of amplicon 3 was difficult to interpret because of the large number of small fragments and the origin of the $28 \mathrm{bp}$ fragment in C.macellaria could not be determined.

Species diagnostic RE digest patterns were observed for four of the five amplicons (Table 4). Five RE digests, Dra I, EcoR V, Hinf I, Rsa I and Ssp I, were diagnostic for screwworm species

Table 4. Estimated fragment sizes for diagnostic and polymorphic RE digests for screwworm species.

\begin{tabular}{|c|c|c|c|c|}
\hline \multirow[b]{2}{*}{ Fragment } & \multirow[b]{2}{*}{ Enzyme } & \multirow[b]{2}{*}{ Pattern } & \multicolumn{2}{|l|}{ Fragments size (bp) } \\
\hline & & & C.hominivorax & C.macellaria \\
\hline 1 & DraI & & $348^{\dagger}$ & 206,142 \\
\hline 1 & $E c \circ R V$ & & 181,172 & 181,167 \\
\hline 1 & Hinc II & A & $348^{\dagger}$ & $348^{+}$ \\
\hline & & B & 307,41 & \\
\hline 1 & Hinf I & & $348^{+}$ & 226,122 \\
\hline 1 & Rsal & & $348^{\dagger}$ & 175,173 \\
\hline 1 & $\operatorname{Ssp} l^{*}$ & & 230,118 & $348^{\dagger}$ \\
\hline 2 & Alu I & $\begin{array}{l}\mathrm{A} \\
\mathrm{B}\end{array}$ & $\begin{array}{l}111,26 \\
137^{7}\end{array}$ & 111,26 \\
\hline 3 & Alu I & & 234,23 & $105,93,37,23$ \\
\hline 3 & Mse I & $\begin{array}{l}\mathrm{A} \\
\mathrm{B}\end{array}$ & $\begin{array}{l}130,39,35,25 \\
70,60,39,35,25\end{array}$ & $70,60,39,35,28,25$ \\
\hline 3 & $M_{s p} I$ & $\begin{array}{l}\mathrm{A} \\
\mathrm{B}\end{array}$ & $\begin{array}{l}257^{\prime \prime} \\
142,115\end{array}$ & $257^{\dagger}$ \\
\hline 4 & Ase' I & $\begin{array}{l}\mathrm{A} \\
\mathrm{B}\end{array}$ & $\begin{array}{l}222,83,40 \\
305,40\end{array}$ & 305,40 \\
\hline 4 & $B f_{a l}$ & & $345^{\circ}$ & 211,134 \\
\hline 4 & $D$ de I & & 285,60 & $345^{\dagger}$ \\
\hline 5 & Hinf I & & 275,45 & $320^{\circ}$ \\
\hline 5 & Mse I & & $129,83,72,36$ & $129,72,52,36,31$ \\
\hline
\end{tabular}


1111111111

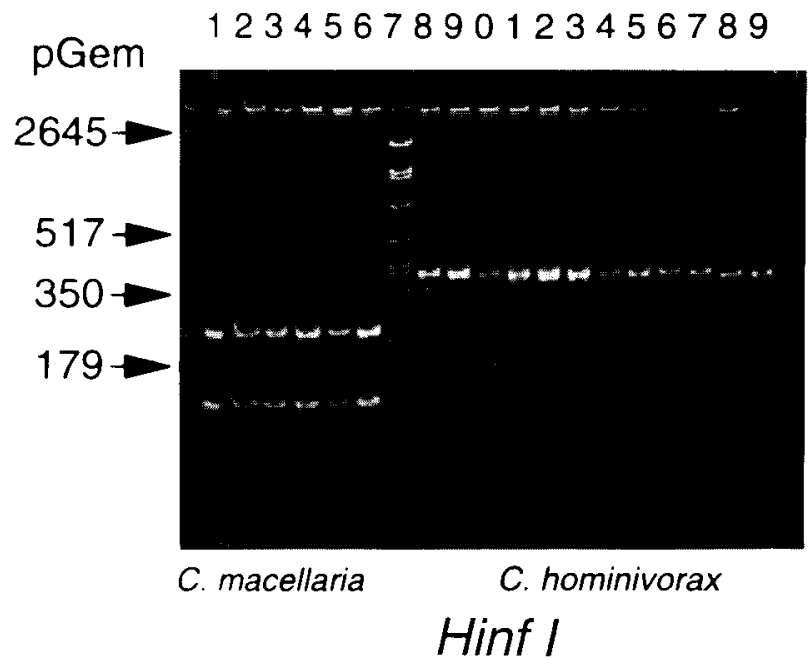

1111111111
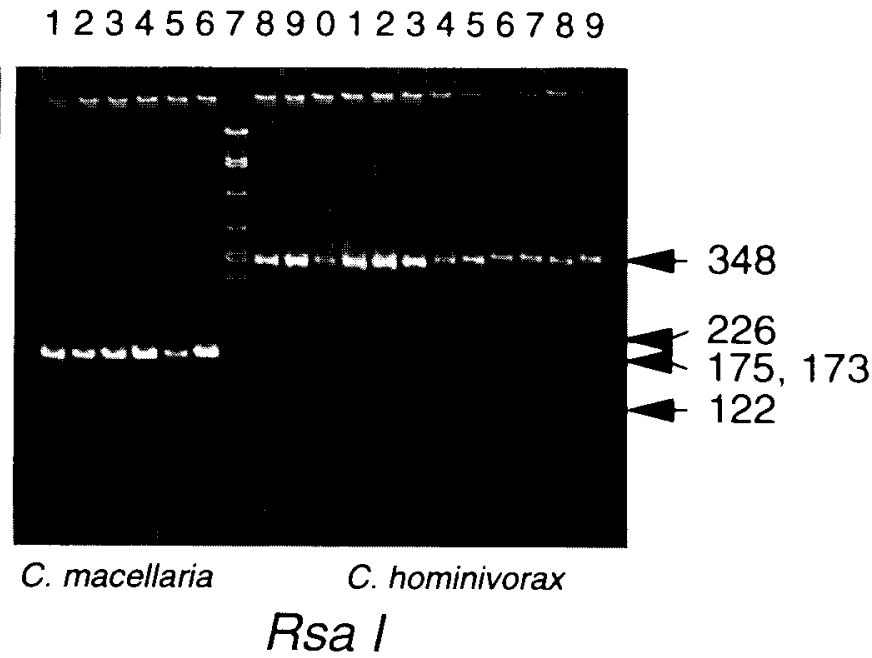

Fig. 1. Restriction enzyme digests of amplicon 1, a 348 bp region of the mitochondrial COI gene. Lanes 1-6 are C.macellaria (lanes 1 and 2. adults Lincoln, Nebraska, U.S.A.; lanes 3 and 4, adults, Tuxtla Gutierrez, Chiapas, Mexico: lanes 5 and 6, adults. Cañas. Guanecaste, Costa Rica). Lane 7 is a molecular standard (pGem, Promega). Lanes 8-19 are C.hominivorax (lanes 8 and 9, adults, Rio Grande do Sul, Brazil: lanes 10 and II, adults. V-81: lanes 12 and 13 adults, OW-87; lanes 14 and 15, egg masses, OW-87; lanes 16 and 17, larvae Trinidad: lane 18. pupa, Guantanamo Naval Base, Cuba: lane 19, larva Jamaica). The single band observed for the Rsa I digest of C.macellaria is composed of two comigrating fragments estimated to be 175 and $173 \mathrm{bp}$.

with amplicon 1 (Fig. 1). Cochliomvia hominivorax was polymorphic for a Hinc II restriction site in amplicon 1 as well. No diagnostic digests were obtained with amplicon 2 , although C.hominivorax was polymorphic for an Alu I site. In amplicon 3. Alu $I$ and Mse $I$ digests resulted in species diagnostic patterns and C.hominivorax was polymorphic for Mse $I$ and Msp $I$ sites. In amplicon $4, B f a I$ and $D d e I$ digests had species diagnostic patterns while Hinf $I$ and Mse $I$ gave diagnostic patterns in amplicon 5. The Ase $I$ digest pattern for amplicon 4 was considered diagnostic until a single C.hominivorax from Costa Rica lacking the C.hominivorax-specific site was observed after the present study was completed. No polymorphic restriction sites were detected in ten C.macellaria from five populations representing North. Central and South America.

\section{Application}

Once diagnostic and polymorphic RE patterns were identified, we used the PCR-RFLP technique to characterize outbreak and questionable samples obtained by the Mexican-American Commission for the Eradication of Screwworm and samples from the CR-91 mass-production strain. One of the primary questions involved in this phase of the study was to determine if the samples could have originated from CR-91, the strain in mass production at the time these samples were submitted. The six samples from the 1992-93 northeast Mexico outbreak were characterized early in this study before our DNA isolation techniques had been perfected. Consequently these samples did not amplify as well as later samples. Of the six samples from the 1992-93 northeast Mexican outbreak, three were second-instar larvae and three were third-instar larvae. We were unable reliably to amplify DNA from the third-instar larvae for the reasons cited above. We were able to obtain amplicon 3 from GB-1361-92, GB-397-93 and GB-466-93, and amplicon 4 from GB-347-93 and GB-397-93. Amplicon 1 did not amplify in any of the samples and amplification of amplicons 2 and 5 was not attempted. GB-1361-92 exhibited Alu $I$ and Mse $I$ digests patterns for amplicon 3 which differed from both C.hominivorax and C.macellaria (two fragments about 153 and 103 bp for $A /$ I I and 5 fragments about 110 . 65, 50, 39 and $35 \mathrm{bp}$ for Mse I) and was identified as a non -screw worm sample. GB-397-93 and GB-466-93 exhibited fragment patterns for $A /$ I $I$ and $M$ se $I$ on amplicon 3 which did not differ from C.hominivorax. GB-347-93 and GB-397-93 exhibited digest patterns for $B f a l$ and $D d e I$ on amplicon 4 which did not differ from those of $C$.hominivorax. These three samples were classified as Chominivorax. Amplicons 1 and 3 were obtained for the Quintana Roo adult. the Cintalapa egg mass, and the Chiapa de Corzo larvae. Amplicon 4 was obtained for the Cintalapa egg mass and the Chiapa de Corzo larvae. All three of these samples were identified as C.hominivorax based upon their fragment length patterns for Hinf I and Rsa I for amplicon I, Alu $I$ and $M$ se $I$ for amplicon 3 . and Bfa $I$ and $D d e I$ for amplicon 4. The pupae found on the desk in Tuxtla Gutierrez exhibited Hinf $I$ and $R s a$ / patterns for amplicon 1 (two fragments. 215 and 133 bp and two fragments. 183 and $165 \mathrm{bp}$, respectively) which differed from both C.hominivorax and C.macellaria.

Haplotypes. based upon composite digest patterns, for each of the unknown samples, several samples representing the geographic range of Chominivorax, and eight CR-9! flies were characterized using the four restriction sites polymorphic in Chominivorax (Table 5)(excluding Ase $I$ in amplicon 4). Six 
Table 5. Haplotypes of CR-91, unknown, and geographic samples of C.hominivorax.

\begin{tabular}{llllll}
\hline & $\begin{array}{l}\text { Amplicon 1 } \\
\text { Hinc II }\end{array}$ & $\begin{array}{l}\text { Amplicon } 2 \\
\text { Ala I }\end{array}$ & $\begin{array}{l}\text { Amplicon } 3 \\
\text { Msp I }\end{array}$ & $\begin{array}{l}\text { Amplicon } 3 \\
\text { Mse I }\end{array}$ & Haplotype \\
\hline CR-91 production strain & & & & & \\
I & A & A & B & A & 2 \\
2 & A & B & A & B & I \\
3 & A & B & A & B & 1 \\
4 & B & A & B & A & 5 \\
5 & A & B & A & B & 1 \\
6 & A & A & B & B & 3 \\
7 & A & A & B & B & 3 \\
8 & B & B & B & A & 6 \\
$1992-93$ outbreak samples & & & & & \\
GB-347-93 & & A & B & & \\
GB-397-93 & & A & B & A & \\
GB-466-93 & & A & B & A & \\
1994 samples & & & & & \\
Adult, Quintana Roo & B & A & B & A & 5 \\
Egg mass, Cintalapa & B & A & B & A & 5 \\
Larvae, Chiapa de Corzo & A & A & B & B & 3 \\
Geographic samples & & & & & \\
Cuba & B & A & B & A & 5 \\
Jamaica & A & B & A & B & 1 \\
Trinidad-7 & A & B & A & B & 1 \\
Trinidad-8 & A & B & A & B & 1 \\
Rio Grande do Sul-4 & A & B & A & B & 1 \\
Rio Grande do Sul-5 & A & B & B & B & 4 \\
Libya & A & B & B & B & 4 \\
Costa Rica, Cañas & B & A & B & A & 5 \\
\hline
\end{tabular}

of the sixteen possible haplotypes were observed and CR-91 contained five of the six. One haplotype was observed in the 1992-93 outbreak samples, two in the 1994 samples, and three in the geographic samples.

\section{Discussion}

The PCR-RFLP technique allowed us to positively identify C.hominivorax eggs, larvae, pupae and adults frozen. dried or preserved in alcohol. Total sample processing from receipt to identification can be completed within $24 \mathrm{~h}$ at a cost of about $\$ 2.50$ for expendables. PAGE allowed us to examine many RE digests rapidly and to visualize fragments as small as $10-15 \mathrm{bp}$. The primary disadvantage of PAGE on non-denaturing gels is that migration is affected by secondary structure of the double-stranded DNA molecule (Sambrook et al., 1989). This complicated determination of the fragment sizes. However, for species identification, migration relative to controls should be used, rather than absolute fragment lengths.

The PCR-RFLP technique has proved to be an efficient and robust technique for the identification of Chominivorax samples. The large number of diagnostic characters reduces the possible impact of undetected variation, rendering individual characters invalid. Application of this technique enabled us to identify or verify the identifications of several field-collected samples. Questions surrounded several of those samples. One, GB-
1361-92, had been classified as C.hominivorax by one identifier and C.macellaria by another. A consensus of C.hominivorax was reached when the two identifiers examined the specimen together. Based upon PCR-RFLP, we determined that this sample differed from both C.hominivorax and C.macellaria and was therefore a third species. The Chiapa de Corzo larvae were initially identified as C.macellaria and later as C.hominivorax, with the consensus being C.hominivorax. We verified the consensus identification. The pupae from the desk were not identified in the field because keys to blow fly pupae are lacking. The origin of these pupae was unknown. Again, our analysis indicated that these were neither C.hominivorax nor C.macellaria. Later morphological examination indicated that the puparia had the posterior spiracles in a cavity and were probably from the family Sarcophagidae. The Cintalapa egg mass was unusual in that it came from an infected wound containing larvae of other muscid and calliphorid species. Cochliomyia hominivorax does not normally infest such wounds. Furthermore, the individual who submitted the sample could not be located to verify the sample and, finally, differentiating C.hominivorax and C.macellaria eggs is difficult. We were able to verify the egg mass identification as C.hominivorax.

In addition to species diagnosis, this technique has the potential ability to characterize within species differences in order to determine the possible origins of C.hominivorax samples. Frequently, questions of fraud, sabotage and false samples surround outbreak samples. Of special importance is the possibility that 
the sample originated from the production factory. Roehrdanz (1989) examined several composite C.hominivorax strains, including three strains which had been in mass production. Although each of these strains was the result of crossing sixteen or more independent lines, Roehrdanz found that all of the composite strains were fixed for a single mitochondrial haplotype. He observed several strains which were polymorphic, containing more than one haplotype. At a later date when these strains were re-examined, all were fixed for one of the two haplotypes. Based upon these findings, we postulated that C.hominivorax composite strains move towards fixation for a single haplotype. and that finding a different haplotype in the field samples would be evidence that they did not originate from the massproduction colony.

Unfortunately, CR-91 was highly variable, containing five of the six haplotypes observed. The high level of variation of CR-91 precluded us from drawing any conclusions as to the relationship of the field samples to CR-91. More study is needed to determine the dynamics of mtDNA haplotypes in massproduction strains before we can determine if the high level of variability in CR-91 is a general or exceptional occurrence.

Several techniques have been published for the identification of insects using molecular characters. Scott et al. (1993) used PCR with a universal primer paired with species-specific primers to differentiate species of the Anopheles gambiae complex. This technique has two disadvantages compared to PCR-RFLP. First, a detailed genetic analysis including sequencing is needed to identify the species specific primers. This procedure must be done for each species to be identified. Second, a failure to amplify may be due to technical difficulties or sample quality rather than the absence of the species-specific sequence. This may result in false negative identifications. Randomly amplified polymorphic DNA (RAPD-PCR) has been used to differentiate species in several insect groups (Black, 1993). RAPDPCR has several drawbacks, the technique frequently gives different results at different laboratories, and contamination. symbionts and parasites can cause confusion (Black, 1993). Hiss et al. (1994) used single-strand conformation polymorphisms (SSCP) to differentiate species in several species groups. This technique has the advantages of not requiring species primers; however, it involves laborious and expensive silver staining of the gels to reveal the single-stranded DNA bands. Haymer $e t a l$. (1994) outlined a technique for identifying species of tephritid fruit flies using species-specific probes. This technique is rapid and inexpensive once the probes have been developed. However, like the species-specific primer technique, it requires DNA sequence information for each species, and failure to obtain a positive reaction may be due to technical reasons resulting in false negatives. The PCR-RFLP technique we used for this study has several advantages over these other techniques. First. false negatives are avoided because universal primers are used. If the DNA in the sample is badly degraded, no PCR amplification will take place and the sample will be characterized as unidentifiable. Second, detailed sequence data are not needed to apply this technique to other species groups. Since the primers are universal, only the fragment patterns for the possible species must be characterized before the technique can be applied. Third, unlike the species-specific primer and probe techniques. this technique will result in RFLP patterns for species which have not previously been characterized. These unknown RFLP patterns may be associated with specific identifications as broader databases of species specific patterns are compiled. Finally, the PCR-RFLP relies on several independent characters for identification. Undetected variability can occur at one or even several of the sites and not preclude accurate identifications due to the large number of characters available. Most of the other techniques rely upon differences in a single region of the DNA and can be confounded by undetected variation within that region.

\section{Acknowledgments}

We thank J. Shaw and T. Galvin for information about the 1992 and 1993 screwworm outbreaks in Mexico and samples of C.hominivorax collected during those outbreaks, and C. J. Whitten for C.hominivorax eggs. G. Moya was a gracious host and provided technical assistance for the collections from Brazil. J. Welch collected the samples from Guantanamo Naval Base, Cuba. K. Pruess suggested several of the primers. T. Galvin, T. Powers, K. Pruess, and R. Rochrdanz provided helpful suggestions and critical reviews of the manuscript. This study was partially funded by Trust Fund Cooperative Agreement No. 58-5440-4-F009 provided by the Food and Agriculture Organization of the United Nations. Samples from Jamaica and Trinidad were collected by FAO collaborators. This work was done in cooperation with the Institute of Agriculture and Natural Resources, University of Nebraska, Lincoln. Nebraska. and is published as Journal Series, Nebraska Agricultural Research Division paper 10938.

U.S. Department of Agriculture, Agricultural Research Service, Northern Plains Area, is an equal opportunity/affirmative action employer and all agency services are available without discrimination.

\section{References}

Barrett, W.L., Jr (1937) Natural dispersion of Cochliomyia americanci. Journal of Economic Entomology: 30, 873-876.

Beard. C.B.. Hamm. D.M. \& Collins, F.H. (1993) The mitochondrial genome of the mosquito Anopheles gambiat: DNA sequence, genome organization, and comparisons with mitochondrial sequences of other insects. Insect Molecular Biology, 2, 103-124

Beesley, W.N. (1991) Origin and eradication of the North African outbreak of New World screwworm. Veterinary Record, 126, 319.

Black, W.C. (1993) PCR with arbitrary primers: approach with care. Insect Molectular Biology: 2, 1-6.

Bushland, R.C., Lindquist, A.W. \& Knipling. E.F. (1955) Eradication of screwworms through release of sterilized males. Science. 122, $287-$ 288.

Chermette. R., Prigent. S. \& Bourdeau. P. (1982) A cas de myiase auriculare due a Cochliomyia hominivorax che\% un chien. Recueil de Médecine Vétérinciire, 158, 583-587.

Clary. D.O. \& Wolstenholme. D.R. (1985) The mitochondrial DNA molecule of Drosophila vakuba: nucleotide sequence. gene organization. and genetic code. Joumal of Molecular Evolution. 22, $252 \cdot 271$ 
Dear, J.P. (1985) A revision of the new world Chrysomyini (Diptera: Calliphoridae). Revista Brasileira Zonlogia, Säo Patulo, 3. 109-169.

El Azazy. O.M.E. (1989) Wound myiasis caused by Cochliomyia hominiworax in Libya. Veterinary Record, 124, 103.

F.A.O. (1990) Manual for the control of the screwnom fly. Cochliomyia hominivoras (Coquerel). Food and Agriculture Organization, Rome.

F.A.O. (1992) The New World Screnworm Eradication Programme. Norh Africa 1988-1992. Food and Agriculture Organization. Rome

Food and Agriculture Organization (1991) New World Screwworm Newsletter No. 14 (January 1991 ).

Graham. O.H. (1985) Symposium on eradication of the serewworm from the United States and Mexico. Miscellaneous Publications, Entomological Society of America. 62, 1-68.

Guimaràes, J.H.. Papavera. N. \& do Prado, A.P. (198.3) As mí́ases na regiäo neotropical (identifacacăo. biologia. bibliografia). Revista Brasileira de Zoologisa, 1, 239-416.

Hall, H.G. \& Smith, D.R. (1991) Distinguishing African and European honeybee matrilines using amplified mitochondrial DNA. Proceedings of the National Academy of Sciences of the United States of America, 88, 4548-4552.

Haymer, D.S.. Tanaka, T. \& Teramae. C. (1994) DNA probes can be used to discriminate between tephritid species at all stages of the life cycle (Diptera, Tephritidac). Joumal of Economic Entomology: 87, $741-746$.

Hiss, R.H. Norris. D.E., Dietrich, C.H., Whitcomb, R.F., West. D.F. Bosio, C.F.. Kambhampati, S.. Picsman, J., Antolin. M.F. \& Black, W.C.. IV (1994) Molecular taxonomy using single strand conformation polymorphism (SSCP) analysis of mitochondrial ribosomal DNA genes. Insect Molecular Biology; 3, 171-182.

Laake, E.W.. Cushing, E.C. \& Parish, H.E. (1936.) Biology of the primary screwworm fly, Cochliomvia americana, and a comparison of its stages with those of C.macellaria. U.S. Department of Agriculture Techical Bulletin, 500. 24pp.

LaCroix. J.M. (1994) DNA fragment size determination on agarose gel by using the application GEL. Computer Applications in Biosciences, 10, 185-187.

Lindquist, D.A., Abusowa. M. \& Hall. M.J.R. (1992) The New World screwworm fly in Libya: a review of its introduction and eradication. Medical and Veterinary Enomologi, 6, 2-8

Mehr. Z., Powers. N.R. \& Konkol, K.A. (1991) Myiasis in a wounded soldier returning from Panama. Joumal of Medical Enomology; 28, $553-554$.

Mitchell, S.E., Cockburn, A.F. \& Seawright, J.A. (1993) The mitochondrial genome of Anopheles quadrimaculatus species A: complete nucleotide sequence and gene organization. Genome, 36, 10581073

Pomonis. J.G. (1989) Cuticular hydrecarbons of the screwworm. Cochliomyia hominivorax (Diptera: Calliphoridac). Joumal of Chenical Ecology: 15, 2301-2317.

Pomonis, J.G. \& Mackley. J.W. (1985) Gas chromatographic composition profiles of surface lipid extracts from screwworm compared by age. sex. colonization and geography. Southwestern Emomologisy, 10, $65-76$.

Pruess, K.P. Zhu, X. \& Powers, T.O. (1992) Mitochondrial transfer RNA genes in a black 1ly, Simulium rittatum (Diptera: Simuliidae), indicale long divergence from mosquito (Diptera: Culicidae) and fruit fly (Diptera: Drosophilidace. Joumal of Medical Entomology: 29 , $64+4-651$

Quecnsland Department of Primary Industries (1994) Biological simulation of a screnworm fly invasion of Australia. Project Report Series Q094005. DPI. Queensland, Australia.

Rawlins. S.C. \& Mansingh. A. (1987) A review of ticks and screwworms affecting livestock in the Caribbean. Insect Science and its Applicafion, 8, 259-267.

Roehrdanz. R.L. (1989) Intraspecific genetic variability in mitochondrial DNA of the screwworm fly (Cochliomvia hominivorax). Biochemical Genetics, 27, 551-569.

Sambrook, J., Fritsch. E.F. \& Maniatis. T. (1989) Molecular Cloning: a Laboratory Manual, 2nd edn. Cold Spring Harbor Laboratory Press. New York.

Scot, J.A., Brogdon. W.G. \& Collins, F.H. ( 1993) Identification of single specimens of the Anopheles gambiat complex by the polymerase chain reaction. American Journal of Tropical Medicine and Hygiene, $49,520-529$.

Searson, J., Sanders, L., Davis, G., Tweddle, N. \& Thornber, P. (1992) Screw-worm fly myiasis in an overseas traveller: case report. Communicable Disease Intelligence, 16, 239-240.

Simon. C. (1991) Molecular systematics at the species boundary: exploiting conserved and variable regions of the mitochondrial genome of animals via direct sequencing from enzymatically amplified DNA. Molecular Techniques in Taxonomy (ed. by G. M. Hewitt, A. W. B Johnston and J. P. W. Young), pp. 33-71. NATO Advanced Studics Institute, H 57. Springer, Berlin.

Simon, C., McIntosh, C. \& Deniega, J. (1993) Standard restriction fragment length analysis of the mitochondrial genome is not sensitive enough for phylogenetic analysis or identification of 17 -year periodical cicada broods (Hemiptera: Cicadidae): the potential for a new technique. Annals of the Entomological Society of America, 86, $\quad 228-238$.

Snow, J.W., Coppedge, J.R., Baumhover, A.H. \& Gorsira, R. (1978) The screwworm Cochliomyia hominivorax (Diptera: Calliphoridae) reinfests the island of Curacao. Netherlands Antilles. Journal of Medical Entomology: 14, 592-593.

Sperling, F.A.H., Anderson, G.S. \& Hickey. D.A. (1994) A DNAbased approach to the identification of insect species used for postmortem interval estimation. Journal of Forensic Sciencies, 39, $418-427$.

Spradbery. J.P. (1991) A Mamual for the Diagnosis of Screw-norm Fly. Canberra ACT, Australia.

Sutherst. R.W.. Spradbery J.P. \& Maywald. G.F. (1989) The potential geographical distribution of the Old World screw worm fly, Chnsomya beziana. Medical and Veterinary Entomology; 3, 273-280.

Taylor, D.B. \& Peterson. R.D. II (1994) Population genetics and gene variation in primary and secondary screwworm (Diptera: Calliphoridae). Annals of the Entomological Society of America, 87, 626-633.

Thomas, D.B. \& Mangan, R.L. (1989) Oviposition and wound-visiting behaviour of the screwworm fly, Cochliomyia hominivorax (Diptera: Calliphoridae). Annals of the Entomological Society of America, 82, $526-534$.

Vargas-Teran. M. (1991) The New World screwworm in Mexico and Central America. World Animal Review: special issue, October 1991, pp. $28-3.5$

Vargas-Tcran. M., Hursey, B.S. \& Cunningham. E.P. (1994) Eradication of the screwworm from Libya using the sterile insect technique. Parasitology Todan: 10, 119-122.

Accepted 9 May 1995 